\title{
THE ONTOGENY OF SALIVA SECRETION IN INFANTS AND ESOPHAGOPROTECTION
}

\author{
Edgard Ferro COLLARES ${ }^{1}$ and Maria Inez Machado FERNANDES²
}

\begin{abstract}
Background - Several studies have reported that severe reflux esophagitis is rare in infants despite the well known high occurrence of regurgitation in early infancy. There is evidence of the importance of saliva for the pre-epithelial protection of the esophageal mucosa. Results - A longitudinal study conducted on healthy infants indicated that the stimulated capacity of saliva secretion (saliva output per $\mathrm{kg}$ of body weight) was significantly higher during their first year of age compared to older children and adults. In addition, this secretion pattern was also observed in low weight newborns during the first weeks of life and persisted in infants with severe protein-calorie malnutrition (marasmus). Conclusion - The greater ability to secrete saliva is an important physiological condition that may protect the infant from acid/pepsin aggression to the esophagus during early stages of development. HEADINGS - Infant. Gastroesophageal reflux. Salivation. Saliva.
\end{abstract}

\section{INTRODUCTION}

Saliva, the name given to the mixture of fluids produced by the salivary glands, has multiple functions in the processes that occur in the upper part of the gastrointestinal tract ${ }^{(44)}$. Updated information about the process of salivary secretion is available in the recent literature ${ }^{(10)}$.

Changes in saliva volume and/or composition have been reported in various pathological conditions affecting children, such as reduced volume and concentration of salivary amylase in children with kwashiorkor ${ }^{(11-13)}$; reduced salivary amylase in children with second-degree protein-calorie malnutrition ${ }^{(70)}$; significant reduction of stimulated and non-stimulated salivary flow in adolescents who had been severely malnourished when children ${ }^{(45)}$; moderate to marked reduction of IgA concentration in saliva in children with severe protein-calorie malnutrition (kwashiorkor and marasmus) ${ }^{(46,69)}$; reduced non-stimulated salivary flow and $\mathrm{pH}$ in type 1 diabetes mellitus ${ }^{(3)}$; reduced salivary amylase concentration in obese boys compared to controls of the same sex but not when compared to $\operatorname{girl}^{(40)}$; increased secretion of calcium, protein, amylase and calcium-containing zymogen granules in stimulated submandibular salivary secretion ${ }^{(2)}$ and increased sodium and chloride concentration ${ }^{(22)}$ in the saliva of patients with cystic fibrosis; reduction of salivary flow rate, of amylase and $\mathrm{K}^{+}$concentration with increased $\mathrm{Na}^{+}$concentration and greater buffering capacity of saliva in children with Down syndrome compared to controls of the same age ${ }^{(57,58)}$, among others. The clinical prevalence of drooling of saliva is high among children with cerebral palsy ${ }^{(32,35)}$. In this serious condition of involvement of the central nervous system, drooling is not a consequence of hypersalivation, but rather of difficulty in swallowing saliva ${ }^{(61)}$ and the reduced flow rate and increased salivary osmolality seem to be caused by reduced fluid intake ${ }^{(50)}$.

\section{Functions of saliva in the oral cavity}

Particularly important among the multiple functions of saliva in the oral cavity are solubilization, formation of the food bolus, identification of flavors, facilitation of mastication and swallowing; clearance of bacteria and food; lubrication of the mucosa, and facilitation of speech. In addition, saliva acts on tooth protection by buffering acids, on the maintenance of a high concentration of calcium phosphate, and on the formation of a protective film on the dental surface ${ }^{(44)}$.

\section{Function of saliva in the esophagus}

Because of its buffering capacity and its content of pre-epithelial defense factors, this exocrine secretion acts on the protection and repair of the esophageal mucosa in situations of aggression such as the presence of gastroesophageal reflux (GER) ${ }^{(42,51,52)}$. There is evidence that salivary bicarbonate is the most important protective factor for the esophageal mucosa against acid/peptic aggression in GER ${ }^{(59)}$.

Correspondence: Prof. Edgard Ferro Collares. Departamento de Pediatria, Faculdade de Ciências Médicas Universidade de Campinas-UNICAMP - CEP: 13083-970 Campinas, São Paulo, Brasil. E-mail: efcollares@hotmail.com. E-mail Maria Inez Machado Fernandes: mimferna@fmrp.usp.br 


\section{Gastroesophageal reflux}

GER is the return of gastric content to the esophagus. The intermittent opening of the lower esophageal sphincter, regardless of the deglutition process, is the most frequent cause of GER in children and adults ${ }^{(66)}$. GER disease (GERD) is a condition which develops when the reflux of stomach contents causes troublesome symptoms and/or complications ${ }^{(63)}$. In infancy, GER accompanied by esophagitis, apnea, chronic respiratory disease, growth deficit or other manifestation represents GERD ${ }^{(5)}$. There is evidence of a genetic influence on the development of GERD ${ }^{(34,41)}$. The most common manifestation of esophageal injury is reflux esophagitis ${ }^{(5)}$. The determinant factors of esophagitis include the frequency of GER, the volume of refluxed gastric content, the potency of the refluxed material, efficacy of esophageal clearance, and the resistance of esophageal tissue to aggression ${ }^{(18)}$.

GER may be occult or may manifest through objective symptoms such as regurgitation and/or vomiting. In infants, regurgitation as a visible expression of GER is frequent and most of the times has a benign course. A survey of parents of healthy American infants during the first year of life indicated the occurrence of at least one daily episode of regurgitation in 50\% of infants aged 0-3 months, with a peak at 4-6 months $(67 \%)$, a frequency that was drastically reduced to $5 \%$ at 10-12 months ${ }^{(38)}$. Another comparable study also concluded that regurgitation is a common symptom among Japanese infants and is reduced with age ${ }^{(33)}$. In addition, several studies evaluating the reflux index (percent time during which $\mathrm{pH}$ was less than 4 in 24-hour esophageal $\mathrm{pH}$ monitoring) suggest that acid reflux is a physiological process more frequently occurring in healthy infants than in healthy adults ${ }^{(49)}$.

On the other hand, several studies have reported that severe reflux esophagitis is rare in infants, especially in those aged less than 6 months $^{(16,21,56,64)}$. The natural history of GER in infants, managed with conservative treatment ${ }^{(9)}$ or with active therapy ${ }^{(55)}$, shows that its course is benign in most cases, whereas $5 \%$ and $2 \%$ of the infants, respectively, develop esophageal strictures. Though a stricture has been described to occur as early as at 3 days and 3 months, it is unusual for a fibrous stricture to develop before 2 years of age ${ }^{(8)}$.

The consequences of esophageal stricture for a child are dramatic. Thus, efficient methods of diagnosis and treatment have been developed over the last decades in order to control this and other complications of $\operatorname{GERD}^{(29,67)}$.

It is intriguing to observe the high frequency of regurgitation in infants and its relative "benign" nature with respect to the occurrence of esophageal disease.

Some factors may explain this phenomenon. The first is related to the potency of the refluxed material. After stimulation of gastric secretion with betazole, acid output (mEq/ $\mathrm{kg} / \mathrm{h}$ ) and pepsin-equivalent output $(\mathrm{mg} / \mathrm{kg} / \mathrm{h})$ were low in newborns and, at 67-110 days of life, reached values corresponding to half those observed in adults ${ }^{(1)}$. At 6 months of life, the production of gastric acid $(\mathrm{mEq} / \mathrm{kg} / \mathrm{h})$ was similar to that observed in children aged 4-9 years and in adults ${ }^{(4,23)}$. The second is milk, the predominant food during this phase of life which by its buffering power protects the esophagus from acid/ pepsin aggression $^{(60)}$. It has been suggested that breast-feeding may have a better protective effect than artificial feeding ${ }^{(6,24)}$. As a third factor, we point out the participation of salivary secretion. Among these functions is the important participation of saliva as a component promoting esophageal clearance (by the swallowing stimulus), buffering (mainly based on bicarbonate) and dilution of refluxed acid, thus reducing the exposure of the esophageal mucosa to aggression ${ }^{(3,18,25)}$. The importance of saliva as a factor of esophageal protection is clearly demonstrated by the fact that the promotion of salivation increases the salivary protective components and the number of swallows and reduces the time of exposure of the esophageal mucosa to acid/pepsin ${ }^{(26,28,37,43,53)}$. Also, patients with esophagitis have a lower saliva secretion compared to controls $^{(7,27)}$ and a lower response to mechanical and chemical stimulation of the epithelial growth factor secreted in the saliva of patients with reflux esophagitis ${ }^{(48)}$.

Regarding the relationship between an acid stimulus and saliva production, two facts are known: 1) the application of acid to the oral mucosa is a potent stimulus of salivary secretion $^{(44)}$ and 2) the exposure of the esophageal mucosa to hydrochloric acid determines a rapid salivation, probably mediated by $\mathrm{pH}$-sensitive receptors located in the esophageal mucosa ${ }^{(19)}$.

\section{Ontogeny of salivary secretion in infants}

Studies of stimulated or non-stimulated saliva secretion in children are fragmented and scarce, corresponding to some age ranges ${ }^{(62,68)}$, or representing a secondary result of the study of production of salivary amylase or of other saliva components $^{(17)}$ or of parotid secretion alone ${ }^{(31)}$. Other studies have evaluated the production of salivary amylase without reporting the saliva volume produced ${ }^{(39,47,54)}$. These studies do not provide a view, even in rough terms, of how saliva secretion evolves during the first months of life of an infant, described as "abundant" by both lay people and health professionals.

Three decades ago we conducted a longitudinal study of saliva and salivary amylase secretion on 10 infants during the first year of life ${ }^{(15)}$. The infants were neonates born at term and with adequate growth and development patterns. Saliva was collected at 1, 15, 30, 45, 60, 90, 120, 150 and 160 days and then at 9 and 12 months of age. For the age in days (except for day 1) the maximum tolerance permitted for saliva collection was \pm 2 days in relation to the scheduled date, whereas for 9 and 12 months the tolerance was one week. None of the infants presented acute or chronic infectious processes on the occasion of saliva collection. The rigorous schedule of the collection dates as well as other reasons caused only 10 of the 36 newborns initially admitted to the study to reach the end of the observation period. The results were compared with those obtained for a group of 18 healthy children aged 1.6-3 years and a group of 18 healthy adults aged 20-30 years. 
Briefly, the technique used, modified from Rossiter et al. ${ }^{(47)}$, was as follows: 1) saliva was collected between 10:00 and 12:00 a.m. 30 minutes or more after the last feeding; 2) the collection of saliva was started 15 seconds after stimulation with one drop of lemon juice applied to the dorsum of the tongue; 3 ) all the saliva secreted into the oral cavity was collected by continuous gentle aspiration for 5 minutes (5 min) using a flexible catheter connected to a calibrated syringe, both of them sterilized ${ }^{(11)}$.

It can be seen in Figure 1 that the saliva volume secreted ( $\mathrm{mL} / 5 \mathrm{~min}$ ) (upper graph) is small in newborns, later increasing and reaching maximum values between 3 and 6 months and then decreasing at 1 year of age to values comparable to those observed in older children. On the other hand, saliva output in $\mu \mathrm{L} / 5 \mathrm{~min} / \mathrm{kg}$ (lower graph) was relatively high at birth compared to children aged 1.6-3 years, reaching extraordinarily high values between 3 and 6 months of life. We also observed that this pattern occurs in low weight newborns during the first weeks of life ${ }^{(14)}$ and persists in infants with severe primary protein-calorie malnutrition (marasmus) ${ }^{(20)}$.

\section{Saliva and esophagoprotection in infants}

To define the participation of saliva in esophageal protection during the first months of life it is necessary to answer

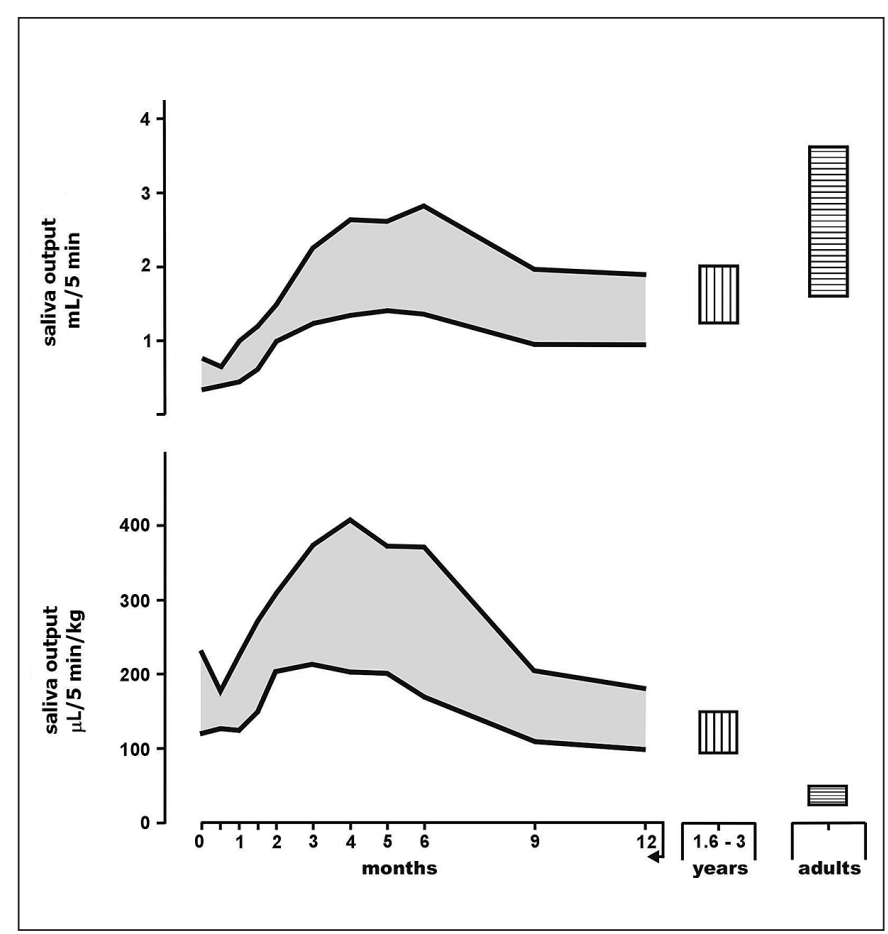

FIGURE 1. Saliva output of infants during the first year of life (longitudinal study) compared to older children (1.6-3 years of age) and young adults, all of them healthy. The upper graph represents the saliva volume secreted over a period of 5 minutes ( $5 \mathrm{~min}$ ) after stimulation with one drop of lemon juice $(\mathrm{mL} / 5 \mathrm{~min})$. The lower graph represents saliva output in $\mu \mathrm{L} / 5 \mathrm{~min} / \mathrm{kg}$. Values are expressed as $95 \%$ confidence intervals. Modified from Collares EF, Brasil MRL and Kawazaki ST ${ }^{(15)}$, with permission. the following question: is the infant's capacity for saliva secretion the same as for other ages?

An analysis of Figure 1 permits us to conclude that in no other phase of life is the rate of production of this exocrine secretion per $\mathrm{kg}$ weight as intense as during the first year of age!

Here we must ask whether saliva is important for esophagoprotection in infants.

Although the reason for this greater saliva output in infants is still unknown, it is reasonable to assume that the phenomenon may be an adaptive response to stimulation of the sensory nerve ends of the esophagus and of the oral cavity by the acid of the refluxed gastric content (regurgitation), more intense during this phase of life. Although obtained in distinct types of study, some evidence in this respect is that during the first months of life a temporal relation can be observed between the increase capacity of saliva secretion and the elevation of acid secretion by the gastric mucosa ${ }^{(1,4,23)}$, a higher frequency of regurgitations ${ }^{(33}$, 38), and the course of the reflux index in healthy infants during the first year of life $\mathrm{e}^{(65)}$.

A greater production of saliva may provide, in addition to the possibility of a higher acid-buffering capacity, a greater quantity of other pre-epithelial defense factors already identified in this secretion and which have been pointed out as possible participants in the protection and repair of the esophageal mucosa ${ }^{(42,51,52)}$. However, no information is available about the evolution, efficiency and degree of participation of the factors of pre-epithelial esophageal mucosal protection against acid/pepsin aggression during the first year of life.

In conclusion, the greater ability to secrete saliva after a stimulus, a phenomenon characteristic of the first months of life, may be an important physiological condition that must protect the infant, at least in part, from acid/pepsin aggression to the esophagus.

\section{Final comments}

The study of salivary secretion is neglected by medical doctors and by gastroenterologists in particular. Most of the available literature reports have been produced by investigators working in the area of oral health. The evidence of the importance of saliva and its components acting on the pre-epithelial protection of the upper digestive tract indicates a promising field of investigation among infants. In addition, it should be emphasized that, over the last decade, this fluid of easy acquisition has been used for the diagnosis and monitoring of some human diseases ${ }^{(30)}$ and studies aiming at its utilization in infants should take into consideration the understanding of the ontogeny of this secretion.

\section{Authors' contributions}

Collares EF and Fernandes MIM participate equally in the manuscript writing processes. 
Collares EF, Fernandes MIM. A ontogenia da secreção de saliva em lactentes e a proteção pré-epitelial do esôfago. Arq Gastroenterol. 2015,52(2):156-60.

RESUMO - Contexto - Vários estudos têm indicado que a esofagite de refluxo é rara em lactentes no primeiro ano de vida a despeito da elevada ocorrência de regurgitação nesta fase da vida. Há evidências da importância da saliva para a proteção pré-epitelial da mucosa esofágica. Resultados - Um estudo longitudinal conduzido em lactentes saudáveis indicou que a capacidade estimulada da secreção de saliva (volume de saliva/kg de peso) foi significativamente elevada no primeiro ano de vida comparada com crianças com mais idade e adultos jovens. Este padrão também foi observado nas primeiras semanas de vida de recém-nascidos com baixo peso e persistiu em lactentes com desnutrição proteico-calórica grave (marasmo). Conclusão - A grande habilidade para secretar saliva é uma importante condição fisiológica que pode proteger o lactente da agressão ácido/péptica do esôfago durante os primeiros estágios do seu desenvolvimento.

DESCRITORES - Lactente. Refluxo gastroesofágico. Salivação. Saliva.

\section{REFERENCES}

1. Agunod M, Yamaguchi N, Lopez R, Luhby AL, Glass GBJ. Correlative study of hydrochloric acid, pepsin, and intrinsic factor secretion in newborns and infants. Am J Dig Dis. 1969;14(6):400-14.

2. Blomfield J, Dascalu J, van Lennep EW, Brown JM. Hypersecretion of zymogen granules in the pathogenesis of cystic fibrosis. Gut. 1973;14(7):558-65.

3. Bouchoucha M, Callais F, Renard P, Ekindjian OG, Cugnenc PH, Barbier JP Relationship between acid neutralization capacity of saliva and gastro-oesophageal reflux. Arch Physiol Biochem. 1997;105(1):19-26.

4. Boyle JT. Acid secretion from birth to adulthood. J Pediatr Gastroenterol Nutr. 2003;37(Suppl 1):S12-6.

5. Boyle JT. Gastroesophageal reflux in the pediatric patient. Gastroenterol Clin North Am. 1989;18(2):315-37.

6. Callahan CW. Increased gastroesophageal reflux in infants: can history provide an explanation? Acta Paediatr. 1998;87(12):1219-23.

7. Campisi G, Lo Russo L, Di Liberto C, Di Nicola F, Bureta D, Vigneri S, et al. Saliva variations in gastro-oesophageal reflux disease. J Dent. 2008;36(4):268-71.

8. Carré IJ. Disorders of oro-pharynx and oesophagus. In: Anderson CM, Burke V, editors. Paediatric Gastroenterology. Oxford: Blackwell Scientific Publications 1975. p. 33-79

9. Carré IJ. Management of gastro-oesophageal reflux. Arch Dis Child 1985;60(1):71-5

10. Catalán MA, Ambatipudi KS, Melvin JE. Salivary gland secretion. In: Johnson LR, editor-in-chief; Ghishan FK, Kaunitz JD, Merchant JL, Said HM, Wood JD, associate editors. Physiology of the Gastrointestinal Tract. Fifth Edition. Oxford: Elsevier Inc; 2012. p. 1229-49.

11. Collares EF, Brasil MRL. [Salivary amylase in the kwashiokor. I - Salivary secretion and salivary concentration before and after nutritional treatment]. Arq Gastroenterol. 1978;15(1):40-5.

12. Collares EF, Brasil MRL. [Salivary amylase in the kwashiokor.II - Salivary concentration and salivary secretion during a no complicated nutritional recuperation] Arq Gastroenterol. 1978;15(2):91-4

13. Collares EF, Brasil MRL. [Salivary amylase in kwashiorkor. III. Investigative study of salivary concentration and secretion in 4 patients presenting complications during nutritional recovery]. Arq Gastroenterol. 1979;16(1):34-8.

14. Collares EF, Brasil MRL, Fernandes MIM. [Saliva secretion and concentration and secretion of salivary amylase in low birth weight infants]. Arq Gastroenterol. 1980;17(4):224-7.

15. Collares EF, Brasil MRL, Kawazaki ST. [Saliva secretion, concentration and secretion of human salivary amylase in 1st year of life] Arq Gastroenterol 1979;16(2):91-4

16. De S, Rajeshwari K, Kalra KK, Gondal R, Malhotra V, Mittal SK. Gastrooesophageal reflux in infants and children in north India. Trop Gastroenterol. 2001;22(2):99-102

17. Dezan CC, Nicolau J, Souza DN, Walter LRF. Flow rate, amylase activity, and protein and sialic acid concentrations of saliva from children aged 18, 30 and 42 months attending a baby clinic. Arch Oral Biol. 2002;47(6):423-7.

18. Dodds WJ, Hogan WJ, Helm JF, Dent J. Pathogenesis of reflux esophagitis. Gastroenterology. 1981;81(2):376-94.

19. Dutta SK, Matossian HB, Meirowitz RF, Vaeth J. Modulation of salivary secretion by acid infusion in the distal esophagus in humans. Gastroenterology. 1992;103(6):1833-41

20. Fernandes MIM. Secreção de saliva, concentração e secreção de amilase salivar na desnutrição. Estudo durante a recuperação nutricional. [Dissertation]. Ribeirão Preto (SP): Faculdade de Medicina de Ribeirão Preto, Universidade de São Paulo-FMRPUSP; 1980
21. Gold BD. Outcomes of pediatric gastroesophageal reflux disease: In the first year of life, in childhood, and in adult...Oh, and should we really leave Helicobacter pylori alone? J Pediatr Gastroenterol Nutr. 2003;37(Suppl 1):S33-S39.

22. Gonçalves AC, Marson FA de L, Mendonça RM, Ribeiro JD, Ribeiro AF, Paschoal IA, et al. Saliva as a potencial tool for cystic fibrosis diagnosis. Diagn Pathol. 2013;8:46.

23. Grand RJ, Watkins JB, Torti FM. Development of the human gastrointestinal tract. A review. Gastroenterology. 1976;70(5 PT.1):790-810.

24. Heacock HJ, Jeffery HE, Baker JL, Page M. Influence of breast versus formula milk on physiological gastroesophageal reflux in healthy, newborn infants. J Pediatr Gastroenterol Nutr. 1992;14(1):41-6.

25. Helm JF, Dodds WJ, Pelc LR, Palmer DW, Hogan WJ, Teeter BC. Effect of esophageal emptying and saliva on clearance of acid from the esophagus. N Engl J Med. 1984;310(5):284-8.

26. Kahrilas PJ. GERD revisited: Advances in pathogenesis. Hepato-Gastroenterol. 1998;45(23):1301-7.

27. Kao CH, Ho YJ, ChangLai SP, Liao, KK. Evidence for decreased salivary function in patients with reflux esophagitis. Digestion. 1999;60(3):191-5.

28. Kongara KR, Soffer EE. Saliva and esophageal protection. Am J Gastroenterol 1999;94(6):1446-52.

29. Lighdale JR, Gremse DA; Section on Gastroenterology, Hepatology, and $\mathrm{Nu}$ trition. Gastroesophageal reflux: Management guidance for the pediatrician. Pediatrics. 2013;131(5):e1684-95.

30. Liu J, Duan Y. Saliva: a potential media for disease diagnostics and monitoring Oral Oncol. 2012;48(7):569-77.

31. Lourie RS. Rate of secretion of the parotid glands in normal children: A measurement of function of autonomic nervous system. Am J Dis Child. 1943;65(3):455-79.

32. Meningaud JP, Pitak-Arnnop P, Chikhani L, Bertrand JC. Drooling of saliva: review of the etiology and management options. Oral Surg Oral Med Oral Patho Oral Radiol Endod. 2006;101(1):48-57.

33. Miyazawa R, Tomomasa T, Kaneko H, Tachibana A, Ogawa T, Morikawa A. Prevalence of gastro-esophageal reflux-related symptoms in Japanese infants. Pediatr Int. 2002;44(5):513-6.

34. Mohammed I, Cherkas LF, Riley SA, Spector TD, Trudgill NJ. Genetic influences in gastro-oesophageal reflux disease: a twin study. Gut. 2003;52(8):1085-9.

35. Morales Chávez MC, Nualart Grollmus ZC, Silvestre Donat FJ. Clinical prevalence of drooling in infant cerebral palsy. Med Oral Patol Oral Cir Bucal. 2008;13(1):E22-6.

36. Moreira AR, Passos IA, Sampaio FC, Soares MSM, Oliveira RJ. Flow rate, $\mathrm{pH}$ and calcium concentration of saliva of children and adolescents with type 1 diabetes mellitus. Braz J Med Biol Res. 2009;42(8):707-11.

37. Namiot Z, Rourk RM, Piascik R, Hetzel DP, Sarosiek J, McCallum RW. Interrelationship between esophageal challenge with mechanical and chemical stimuli and salivary protective mechanisms. Am J Gastroenterol. 1994;89(4):581-7.

38. Nelson SP, Chen EH, Syniar GM, Christoffel KK. Prevalence of symptoms of gastroesophageal reflux during infancy. A pediatric practice-based survey. Arch Pediatr Adolesc Med. 1997;151(6):569-72.

39. Nicory C. Salivary secretion in infants. Biochem J. 1922;16(3):387-9.

40. Oliveira CG, Collares EF, Barbieri MA, Fernandes MIM. [Production and concentration of saliva and salivary amylase in obese children]. Arq Gastroenterol 1997;34(2):105-11.

41. Orenstein SR, Shalaby TM, Barmada MM, Whitcomb DC. Genetics of gastroesophageal reflux disease: A review. J Pediatr Gastroenterol Nutr. 2002;34(5): 506-10.

42. Orlando RC. The pathogenesis of gastroesophageal reflux disease: The relationship between epithelial defense, dysmotility, and acid exposure. Am J Gastroenterol. 1997;92(4 Suppl):3S-5S. 
43. Patel R, Launspach J, Soffer E. Effects of cisapride on salivary production in normal subjects. Dig Dis Sci. 1996;41(3):480-4.

44. Pedersen AM, Bardow A, Jensen SB, Nauntofte B. Saliva and gastrointestinal functions of taste, mastication, swallowing and digestion. Oral Dis. 2002;8(3):117-29.

45. Psoter WJ, Spielman AL, Gebrian B, Rudolph StJ, Katz RV. Effect of childhood malnutrition on salivary flow and pH. Arch Oral Biol. 2008;53(3):231-7.

46. Reddy V, Raghuramulu N, Bhaskaram C. Secretory IgA in protein-calorie malnutrition. Arch Dis Child. 1976;51(11):871-4.

47. Rossiter MA, Barrowman JA, Dand A, Wharton BA. Amylase content of mixed saliva in children. Acta Paediatr Scand. 1974;63(3):389-92.

48. Rourk RM, Namiot Z, Sarosiek J, Yu Z, McCallum RW. Impairment of salivary epidermal growth factor secretory response to esophageal mechanical and chemical stimulation in patients with reflux esophagitis. Am J Gastroenterol. 1994;89(2):237-44.

49. Rudolph CD, Mazur LJ, Liptak GS, Baker RD, Boyle, JT, Colletti RB, et al. Guidelines for evaluation and treatment of gastroesophageal reflux in infants and children: Recommendations of the North American Society for Pediatric Gastroenterology and Nutrition. J Pediatr Gastroenterol Nutr. 2001;32(Suppl 2): $\mathrm{S} 1-31$.

50. Santos MT, Guaré RO, Leite MF, Ferreira MC, Durão MS, Jardim JR. Salivary osmolality in individuals with cerebral palsy. Arch Oral Biol. 2010;55(11):855-60.

51. Sarosiek J, McCallum RW. Do salivary organic components play a protective role in health and disease of the esophageal mucosa? Digestion. 1995; 56(Suppl 1):32-7.

52. Sarosiek J, McCallum RW. Mechanisms of oesophageal mucosal defense. Baillière's Clin Gastroenterol. 2000;14(5)701-17.

53. Sarosiek J, Scheurich J, Marcinkiewicz M, McCallum RW. Enhancement of salivary esophagoprotection: Rationale for a physiological approach to gastroesophageal reflux disease. Gastroenterology. 1996;110(3):675-81.

54. Sevenhuysen GP, Holodinsky C, Dawes C. Development of salivary $\alpha$-amylase in infants from birth to 5 months. Am J Clin Nutr. 1984;39(4):584-8.

55. Shepherd RW, Wren J, Evans S, Lander M, Ong TH. Gastroesophageal reflux in children. Clinical profile, course and outcome with active therapy in 126 cases. Clin Pediatr. 1987;26(2):55-60.

56. Shub MD, Ulshen MH, Hargrove CB, Siegal GP, Groben PA, Askin FB. Esophagitis: A frequent consequence of gastroesophageal reflux in infancy. J Pediatr. 1985;107(6):881-4.

57. Siqueira WL, Bermejo PR, Mustacchi Z, Nicolau J. Buffer capacity, pH, and flow rate in saliva of children aged 2-60 months with Down syndrome. Clin Oral Investig. 2005;9(1):26-9.
58. Siqueira WL, Siqueira MF, Mustacchi Z, Oliveira E, Nicolau J. Salivary parameters in infants aged 12 to 60 months with Down syndrome. Spec Care Dentist. 2007;27(5):202-5.

59. Skoczylas T, Yandrapu H, Poplawski C, Asadi M, Wallner G, Sarosiek J. Salivary bicarbonate as a major factor in the prevention of upper esophageal mucosal injury in gastroesophageal reflux disease. Dig Dis Sci. 2014;59(10):2411-6.

60. Sutphen JL, Dillard VL. Effects of maturation and gastric acidity on gastroesophageal reflux in infants. Am J Dis Child. 1986;140(10):1062-4.

61. Tahmassebi JF, Curzon ME. The cause of drooling in children with cerebral palsy - hypersalivation or swallowing defect? Int J Paediatr Dent. 2003;13(2):106-11.

62. Torres SR, Nucci M, Milanos E, Pereira RP, Massaud A, Munhoz T. Variations of salivary flow rates in Brazilian school children. Braz Oral Res. 2006;20(1):8-12.

63. Vakil N, van Zanten SV, Kahrilas P, Dent J, Jones R; Global Consensus Group. The Montreal definition and classification of gastroesophageal reflux disease: A global evidence-based consensus. Am J Gastroenterol. 2006;101(8):1900-20.

64. Vandenplas Y, Franckx-Groossens A, Pipeleers-Marichal M, Derde MP, SacréSmits L. Area under $\mathrm{pH} 4$ : Advantages of a new parameter in the interpretation of esophageal $\mathrm{pH}$ monitoring data in infants. J Pediatr Gastroenterol Nutr. 1989;9(1):34-9.

65. Vandenplas Y, Goyvaerts H, Helven R, Sacre L. Gastroesophageal reflux, as measured by 24-hour $\mathrm{pH}$ monitoring, in 509 healthy infants screened for risk of sudden infant death syndrome. Pediatrics. 1991;88(4):834-40.

66. Vandenplas Y, Hassall E. Mechanisms of gastroesophageal reflux and gastroesophageal reflux disease. J Pediatr Gastroenterol Nutr. 2002;35(2):119-36.

67. Vandenplas Y, Rudolph CD, Di Lorenzo C, Hassall E, Liptak G, Mazur L, et al Pediatric gastroesophageal reflux clinical practice guidelines: Joint recommendations of the North American Society for Pediatric Gastroenterology, Hepatology, and Nutrition (NASPGHAN) and European Society for Pediatric Gastroenterology, Hepatology, and Nutrition (ESPGHAN). J Pediatr Gastroenterol Nutr. 2009;49(4):498-547.

68. Watanabe S, Dawes C. Salivary flow rates and salivary film thickness in five-yearold children. J Dental Res. 1990;69(5):1150-3.

69. Watson RR, McMurray DN, Martin P, Reyes MA. Effect of age, malnutrition and renutrition on free secretory component and $\operatorname{IgA}$ in secretions. Am J Clin Nutr. 1985;42(2):281-8.

70. Watson RR, Tye JG, McMurray DN, Reyes MA. Pancreatic and salivary amylase activity in undernourished Colombian children. Am J Clin Nutr. 1977;30(4):599-604.

Received 30/9/2014

Accepted 18/12/2014 